\title{
NEW OPPORTUNITIES FOR FARM ACCOUNTING
}

\author{
Authors: Josep Maria Argilés and Eric John Slof
}

July 2000

We acknowledge the support of the FADN Division of the D.G. VI for Agriculture of the European Commission and the XCAC office in Barcelona. 


\section{ABSTRACT}

There is a gap between the importance given to accounting and the low level of bookkeeping and accounting practice in the agricultural sector. Current general accounting rules do not adapt very well to the particularities of farming and are difficult and expensive to implement. The Farm Accountancy Data Network (FADN) and IASC's Proposed International Accounting Standard on Agriculture (PIASA) could be key elements to improve the use of accounting in European farms. The PIASA provides a strong conceptual framework but might need further instruments for its implementation in practice. FADN is an experienced network that has elaborated very detailed farm accounting procedures. Empirical data indicate that current FADN reports are already considered useful by farmers for different purposes. Some changes in the FADN procedures are suggested, while some aspects of FADN are worthwhile for the future IAS on agriculture.

JEL: M41

Key words: Agricultural accounting, International Accounting Standards, Farm Accountancy Data Network, European Union, use of farm accounting. 


\section{INTRODUCTION}

In spite of its relative importance in the economy of many countries and its growing interrelationships with other sectors, agriculture has traditionally not received much attention from accounting researchers, practitioners and standard setters. Consequently, current accounting principles typically do not respond very well to the particular characteristics of agricultural business and the information needs of farmers and their stakeholders. As an example, so far there is no standard for biological assets, whose valuation is difficult and controversial.

Together with other reasons, like the generally lower level of managerial sophistication and fewer economic means in the sector, the limited appropriateness of general accounting principles has led to a situation in which farmers are more reluctant to prepare accounting reports and use this kind of information than the agents in other economic sectors (Poppe, 1991; Poppe and Breembroek, 1992). Moreover, because of their size or legal form, most European farms have no legal obligation to publish financial statements, and when farmers use accounts, they typically only do so to comply with tax and subsidy requirements, as several authors, like Kroll (1987), André (1987), or Sabaté and Enciso (1997), have pointed out.

On the other hand, it is generally believed that accounting can improve farm management and lead to better farm performance (see for example, Luening, 1989; Allen, 1994). Empirical work by Garcia, Sonka and Mazzacco (1983) found that farmers who used a formal record system over time improved their ability to use the kind of information the system produced. For example, they observed that farmers who prepared financial statements were more likely to 
make cash flow projections than those who were not involved in financial accounting. Streeter (1990) studied five farmers who were using electronic information systems, and observed how these farmers discovered by themselves that accounting functions would improve their management information systems. Thus, accounting is a necessary precondition to generate useful information for decision making, and it is also a good complement for management information systems.

Furthermore, agricultural lenders often claim more and better accounting information (Bronstien, 1995; Crane and Leatham, 1995), which is consistent with empirical evidence that accounting data makes a significant contribution to explaining and predicting farm failure (Argilés, 1998). Given the government interference in many agricultural markets in many countries, also policy makers have a need for accounting information.

We can conclude therefore that there exists an external demand for accounting information in agriculture and that this information would also be useful for the farmers themselves. Farmers do not get involved in accounting, however, because current accounting rules do not adapt very well to their type of business and are difficult and expensive to implement.

The objective of this paper is to provide some suggestions that could help closing the gap between the importance conferred to accounting and the low level of bookkeeping and accounting practice in the agricultural sector. We believe that the combination of two already existing tools can have an important role in this respect: (1) the European Union's Farm Accountancy Data Network $\left(\mathrm{FADN}^{1}\right)$, and (2) the Proposed International Accounting Standard on Agriculture (PIASA) which has recently been released by the International Accounting Standards Committee (IASC). We think that the PIASA makes a good conceptual framework, while FADN can provide the practical tools to make it operational. 
The remainder of this paper is organized as follows. Section two analyzes the contribution of the PIASA and argues that it needs further tools for implementation. Section three provides further background information about FADN. Section four reports on empirical findings regarding farmers' experience with accounting and FADN. Section five compares FADN and the PIASA framework, and tries to develop suggestions to make FADN compatible with the PIASA, on the one hand, and to incorporate some of the experience of FADN into the final version of the future IAS, on the other hand. Section six, finally, contains the main conclusions.

\section{KEYS TO THE IMPROVEMENT OF ACCOUNTING IN EUROPEAN AGRICULTURE}

Prior to the PIASA, guidance for farm accounting could be found from the AICPA (American Institute of Certified Public Accountants, 1996) and the CICA (Canadian Institute of Chartered Accountants, 1986). Both provide interesting definitions and recommendations for valuation of agricultural assets. Also the French "Plan Comptable Général Agricole" (PCGA) from 1986 set up standards for certain agricultural assets and gave detailed guidelines for the accounting of agricultural transactions and the presentation of financial statements.

However, we believe that the PIASA introduces important improvements. The first improvement relates to the definition, valuation and presentation of (1) biological assets, (2) agricultural produce, and (3) agricultural land, all of which are of great importance for the transformative capabilities of agricultural businesses and generation of income. Biological assets are defined as living animals and plants that are controlled as a result of past events, agricultural produce as the harvested product of biological assets awaiting sale, processing, or consumption, and agricultural land as land that is used directly to support and sustain 
biological assets in agricultural activity (IASC 1999). Further helpful distinctions are made between mature and immature biological assets, and between consumable biological assets (that are themselves to be harvested) and bearer biological assets (that are not the primary agricultural produce themselves but only bear it for harvest). Finally, the recognition that biological assets are typically managed in groups can be very helpful in determining their value in practice.

The nature of farming makes a historical cost-based valuation of biological assets, and consequently also of agricultural produce, inherently difficult, because the physical state of biological assets typically changes over time, i.e. they strengthen, mature, fatten, etc. Furthermore, their quantity does not only depend on buying and selling activities, but is also determined by such processes as procreation, growth, and death. Therefore, many assets owned by a farm at a certain moment in time are typically substantially different from how they were when acquired, or have never been acquired at all. In this sense they are similar to the produce of manufacturing firms, and product costing techniques could be applied to assign the historical cost of inputs used to outputs obtained. The problems caused by joint-cost situations, however, usually far exceed the complexity already encountered in manufacturing environments.

Although some authors (for example, Launay, Beaufrere and Debroise, 1967; Alonso and Serrano, 1991; Pérez, 1993) have made suggestions to overcome some of the difficulties, several others have concluded that historical costs are generally not very informative to users and allocations to individual assets are necessarily very arbitrary in most cases (Lewis and Jones, 1980; Domínguez, 1981; Kroll, 1987; Sturguess, 1994). In spite of the fact that this situation has long been recognized, agriculture has not been an exception in the preference of standard setters for historical cost valuation. The French PCGA, for example, strictly adheres 
to the historic cost principle. Also the AICPA (1996) and the CICA (1986) recommended the historical cost principle as the main reference for asset valuation, although these institutes also recognized that there may be exceptional situations in which realizable value could be considered as an alternative.

The PIASA breaks with this tradition and turns fair value into the rule instead of the exception. The Steering Committee that is developing the standard, expressed that fair value is a better basis for the valuation of biological assets, agricultural produce, and agricultural land than historical cost (IASC, 1999). It further concluded that market price is an indicator of fair value when active markets exist, and that market prices are more objective than allocations of historic cost. It also pointed out that for most agricultural assets relatively efficient markets exist and that therefore fair value can be obtained relatively easily. In the absence of active and efficient markets, the PIASA suggests to determine fair value based on the most recent market price for that class of asset, or market prices for similar or related assets.

Simplicity is another improvement of the PIASA. Kroll (1987) regretted that the complexity in asset valuation and accounts of the French PCGA was an important barrier to its use in practice. We believe that the PIASA solves these difficulties, as it defines clear and simple valuations for agricultural assets. Procedures for changes in carrying amount for these assets are also easy to be implemented. Finally, the presentation of financial statements is less rigid and complicated than in the PCGA.

With reference to the European context, we observe that in essence the PIASA appears to be in accordance with the IVth Directive, although some contradictions between these two frameworks can be found. More, and more serious problems are likely to arise from conflicts between the PIASA and accounting standards of individual EU members. For example, asset 
valuation based on current value is not contradictory to the IVth Directive, which in Article 33 explicitly refers to the possibility of valuing fixed assets and inventories at their replacement value, and also permits inflation adjustments of historic cost data. However, the Directive excludes land from the assets that may be valued at replacement value, and moreover, many EU member states have not adopted this option in their national rules at all. The relationship between the EU and the IASC is a complex matter, as can be seen from the discussion between Flower (1997, 1998) and Cairns (1997). While certainly interesting by itself, it is beyond the scope of this paper to explore this issue further. Nonetheless, most European farms will be in a position to use the PIASA, given that because of their small size or legal form, they have no legal obligation to publish financial statements according to any specific accounting rules.

In all, the PIASA is a very interesting document for professional accountants, to whom it provides an excellent conceptual framework. We believe, however, that it is unlikely that this standard by itself will overcome the barriers to the implementation of accounting in most farms, as it cannot change the economic and managerial limitations of the farmers and their farms. The standard will therefore not be of any direct help to most farmers, who rather need a "cooking book," and probably also someone who shows them how to read it. In our opinion, it would be very helpful for this reason if the future IAS were complemented with (optional) tools for its implementation and mechanisms for the transfer of accounting know-how. We further think that FADN could provide both the tools and transfer mechanisms.

For many years FADN has been developing general procedures and detailed guidelines for farm accounting, solving many of the practical problems that arise in agriculture. Currently it has a very structured body of rules for data collection (including codifications which could easily be turned into account numbers) and aggregation in standardized reports that are very 
similar to the income statement and balance sheet. We believe that this body of rules is very close to being an accounting plan and that it could become an effective guideline for the implementation and development of the PIASA in Europe, and maybe also elsewhere in the world. As Poppe and Beers (1996) point out, in the absence of pronouncements on agriculture from other authorities, FADN has already been fulfilling the role of a quasi standard-setting body in practice, although it has no legal or professional status in this sense at all. Furthermore, being in the field for many years FADN agencies have specialized in farm accounting issues and keep close contact with thousands of farmers. These agencies would be in an excellent position to transmit accounting know-how.

While the relative rigidity of an accounting plan can be considered an important shortcoming in many other sectors, its advantages could easily outweigh this drawback in the case of agriculture. Accounting plans have proven to be a cheap and effective means to disseminate accounting know-how, particularly in relatively less sophisticated environments. For example, Chaveau (1995) refers to the Spanish accounting plan as an "agent of development and innovation," that brought together theoretical problems and practical solutions. He states that the Spanish plan "provides a logical basis for accounting education, strengthening professional adaptability, facilitating the implementation of methodologies and training of large numbers of people" (p.136, emphasis added). While admittedly far from perfect, it is fair to say that the Spanish plan has been an important tool for the transition of Spanish accounting from a rather backward position to a level comparable to that of most other Western European countries.

In a similar vein, Choi and Mueller (1992) pointed out that developing countries can (and did) import accounting technology developed elsewhere in the world without having to incur development costs, and explicitly refer to the example of the many former French colonies that 
have adopted variations of the French accounting plan and now strongly adhere to them. It is also interesting to recall that the "inventor" of accounting plans, Eugen Schmalenbach, in the first place thought of them as a means of education (Richard 1995).

\section{THE FARM ACCOUNTING DATA NETWORK (FADN)}

FADN was created in the context of the Common Agricultural Policy (CAP), which has been one of the cornerstones of the European economic and political integration process. To date the European Union's Directorate for Agriculture still is the one with by far the largest budget. It is not surprising therefore that the Commission of the European Community (CEC) has a need for information on the financial performance and condition of farms to support decision making for and control of the CAP. This information need is not limited to aggregate macro-economic data, but also extends to the level of individual farms, and the European Commission had to make an effort to obtain standardized information. For this reason the Council of the European Commission created the FADN. This network collects accounting information at the level of individual farms, and gathers every year data from a rotating sample of 60.000 professional farms across all member states.

The six founding member states of the European Economic Community (EEC) set up the Common Agricultural Policy (CAP) to implement the five objectives that were promulgated in Article 39 of the Treaty of Rome. The desire to monitor the performance of CAP led to a need for information about the situation of the agricultural sector in the member states. Objective information about the performance and income of the different types of farms existing in the EU was required which could not be found in the macro-economic "Economic accounts for 
Agriculture" provided by EUROSTAT. Therefore FADN was created in 1965, through Regulation (EEC) 79/65 of the Council. At least at that time, FADN was only conceived as a complementary source of statistical information for policy makers and not as a tool to be used by farmers or other stakeholders (CEC, 1991).

Complete documentation of FADN can be found in CEC $(1997 ; 1998)$. Its basic features can be summarized in the following points:

- FADN aims to gather accounting data on the performance and income of farms in the EU.

- $\quad$ FADN data are not obtained at a macro-economic level, but from a random rotating sample of approximately 60.000 individual farms across all member states.

- The field of observation of FADN is that of "commercial" farms. A minimum European Size Unit is established in each member state to define the commercial farm.

- $\quad$ The sample is stratified by region, farm size and type of farming.

- FADN is a network of networks of accounting offices. The accounting offices differ between the member states. Some are commercial accounting offices that adapt records already kept for tax purposes or investment aids. In other countries the accounts are prepared by research institutes, universities or agricultural trade unions. Many of the accounting offices only keep the records for the purpose of FADN.

The data collected by the accounting offices are transmitted to regional committees and from there to the national liaison offices. The national liaison offices then forward them to the European Commission in Brussels, where FADN's management committee checks the validity of the data and stores them in a database. 
- Depending on the country, either the regional committees or the national offices select the sample for a given stratification. However, the final sample is always conditioned by the participation of the farmers, which is voluntary.

- $\quad$ FADN data are confidential, which means that they can not be disclosed or used for tax purposes. Therefore, a minimum number of farms is required for each stratum to assure anonymity. FADN never publishes nor otherwise provides information about individual farms.

FADN data are collected through a questionnaire, the "Farm Return," from a variety of sources, such as bank statements, invoices, etc. The Farm Return is the core of the FADN data collection procedure and is filled out by the farms with the assistance of the accounting offices. It includes the following 13 sections:
A. General information of the farm.
B. Type of occupation (tenure).
C. Labor input.
D. Number and value of livestock.
E. Livestock purchases and sales.
F. Costs.

G. Land and buildings, deadstock and circulating capital.

H. Debts. 
I. Value added tax.

J. Grants and subsidies.

K. Production.

L. Quota.

M. Compensations in arable farming.

Besides other types of information which are expressed in physical measures only, the data collected by FADN concern assets, liabilities, revenues and expenses of the farms in the sample, and is summarized in reports similar to balance sheets and income statements. Since many European farms do not provide reliable financial statements and when they do these statements are not directly comparable between countries, FADN had to develop and put in practice detailed guidelines and resolve both specific and general farm accounting issues. In this way, the Farm Return has developed to a level of complexity and comprehensiveness comparable to the national accounting plans of countries like France or Spain. (The Appendix contains three excerpts from the Farm Return to illustrate this point.)

\section{FARMERS' EXPERIENCE WITH FADN AND ACCOUNTING}

In preceding sections of this article we have argued that farmers typically do not prepare financial statements, because current accounting rules do not adapt well to the particularities of agriculture. Farmers consider that the benefits of accounting reports do not outweigh the cost and effort of preparing them, or learning how to prepare them. However, if given appropriate 
tools - and FADN provides the basis for such tools - it can be expected that farmers would produce and use accounting information. In this section we will provide some empirical data to support these assertions. First, we report on the results obtained from a survey about the use farmers make of FADN reports. Second, we summarize the interviews we conducted at a few farms.

\subsection{Survey}

With the support of the regional FADN office in Catalonia we collected data on the usage of FADN reports. The aim of this survey was to find out whether farmers only prepared reports for the purpose of FADN or also used them for additional purposes. It is reasonable to assume that farmers will only use the FADN reports for additional purposes if they consider that these reports are somehow useful to them. The usage of the reports would therefore indicate that farmers do not necessarily dislike accounting data per se but that they will use them if they are relevant and available to them. Furthermore, usage of the information obtained with FADN methods, would show that its approach is not only relevant to policy makers but also to farmers.

Questionnaires were sent to five agencies that kept the records of in total 170 farms that remained in the FADN sample for a period of five years. According to the FADN office, only very few of these farms had prepared or used accounting information before joining FADN. The questionnaires were filled out by the officers who were responsible for the relationship with the individual farms, and were returned to us by the offices. We received in this way usable replies from four offices, covering in total 137 farms (accumulating therefore in five years a total of 685 observations). 
The questionnaire asked for each farm and for each year, whether the farm had made use of the FADN report for any of the following four purposes: (1) loan applications, (2) subsidy applications, (3) income tax filing, (4) managerial decision making, or exclusively prepared the reports for FADN. Results are shown in table 1 and 2.

Insert table 1 approximately here

It can be seen that in more that half of the cases farms used the information obtained from the FADN reports for some other purpose. Only $42,3 \%$ of the farms only cooperated in the accounting network for the sake of FADN and never tried to take advantage of this information for alternative uses. Taking into account that most farms did not prepare or use accounting information before joining FADN, the usage of the reports can be considered remarkably high, which supports the idea, already suggested by Garcia, Sonka and Mazzacco (1983) and Streeter (1990), that the availability of accounting information leads to its use.

Insert table 2 approximately here 
Among the farms that made alternative use of the FADN reports, tax filing and management decision making were clearly the most preferred uses. $41,6 \%$ of the farms in our sample used the FADN reports for the purpose of decision making at least once in the period studied, and most of these $(38,0 \%$ of the total sample) did so persistently over each of the five years. This indicates that many farmers believe that the information from the FADN reports is relevant to their business. Very likely this information should also be relevant therefore to other stakeholders.

Only few farms used the accounting records for loan and subsidy applications. Probably this explains more about our sample demographics than about the usefulness of the FADN reports for these particular purposes, however. Catalonian farms are normally equity financed and seldom apply for loans. The common types of agricultural holding in this region (hog, poultry, and dry fruits) are currently not eligible for most subsidies, either. It could therefore well be that those farms that applied for a loan or a subsidy actually used the FADN reports relatively frequently, but there were just only very few of them in our sample.

We explored whether the type of farm (hog, poultry, dry fruit, etc.) was related to the responses given, but we have not found any significant differences in this respect.

\subsection{Interviews}

Confidentiality is an important commitment of FADN. It was therefore impossible for us to get in direct contact with the farms from our survey sample, or any other that collaborate with the network. However, we had the opportunity to interview five farmers who prepared financial statements (three hog farms, one rabbit farm, and one dairy farm) and one auditor who counts several other farms among his clients. The aim of these interviews was to learn more about the 
day-to-day experience with agricultural accounting.

A first observation was that agriculture is indeed increasingly interrelated with other sectors of the economy and that this interrelationship leads to the perception of an increased need for accounting data. The three hog farms were required to prepare accounts because they were integrated in a larger organization (a co-operative or an agribusiness firm). The dairy and the rabbit farm were obliged to prepare accounting reports because of tax requirements. All felt that they needed to provide to financial data to satisfy the information demanded by their environment.

All farms expressed that apart from satisfying external information demands, they found financial accounting useful and necessary for internal decision making. Nevertheless, some of the people interviewed wanted to make clear that more information is needed for good farm management than just financial accounting numbers. The dairy farm, for example, apart from financial accounting reports, used a computerized management information system that was principally fed with physical data (liters of milk daily obtained, number of cows at different stages of pregnancy, etc.).

We observed a divergence of accounting practices employed by the farms, mainly concerning revenue recognition, expenses and treatment of subsidies (some using accruals, others the cash basis). We also observed different approaches to fixed asset valuation and depreciation, although all farms coincided in valuing livestock at end-of-period market prices, simplicity being the most important reason to opt for this valuation method. The calculation of historic costs for livestock was considered by them as very difficult and problematic. ${ }^{2}$

All farms said that they would like to follow GAAP but run into difficulties when trying to

$$
-16-
$$


apply them to specific situations and improvise solutions. It is obvious that if someone should want to compare the financial statements of these farms, he or she would have severe problems because of the inconsistencies between them. Both users and preparers would therefore benefit from more guidance and standardization.

\section{COMPARISON OF THE ACCOUNTING PRINCIPLES APPLIED BY FADN AND THE} PIASA

This section compares the accounting data provided by FADN to the PIASA. Particularly, the valuation of assets, the recognition and valuation of revenues and expenses, and their presentation in the financial statements are reviewed. In this, we try to identify, on the one hand, aspects of FADN which should be modified to get in line with the PIASA, and on the other hand, contributions FADN could make to the IASC's effort.

\subsection{Assets and their valuation}

In most cases FADN uses market prices for the valuation of non-monetary assets. Specifically, livestock is valued at prices prevailing at the beginning and ending of the accounting period. The valuation of land is based on the market price for non-rented land with similar characteristics regarding location, quality and use, from which any development costs are deducted. Depreciable fixed assets, such as buildings and machinery, are valued at replacement cost at the beginning and end of the accounting period. Replacement cost is defined here as the price that the farm would pay for a new similar asset. Accordingly, depreciation is calculated on a replacement-cost basis. To the extent that replacement prices are not available or not reliable, FADN updates acquisition cost with specific price indices. 
Stock of agricultural produce is valued at realizable value at the balance sheet date. It should be pointed out that sales costs are not deducted here.

In essence therefore, FADN appears to be in accordance with the PIASA. In some important aspects, however, departures can be found. First, FADN uses current values for all nonmonetary assets, while the PIASA does not refer to the valuation of assets other than agricultural produce, biological assets and agricultural land, which means that these assets should be valued on historical cost basis. It seems that FADN applies current value for the sake of simplicity, because many farms, particularly those recently incorporated into the network, do not have information about the historical costs of their assets. Valuation at replacement values may mean an easy and uniform rule for statistical purposes, but the assumption of active and efficient markets - which justifies IASC's choice of fair value in the case of agricultural produce, biological assets and agricultural land - can hardly be applied to all assets. We believe that it would be easy for FADN to adapt to historical-cost valuation. Additionally, this would provide a better basis to compare income and assets of farms with modern and old equipment.

Second, questions arise about the treatment of the cumulative changes in current value. FADN includes the holding gains or losses without any further disclosure in owners' equity, while the PIASA would require the creation of a revaluation reserve. Like other existing accounting standards (SSAP15, FAS 33, IAS15, IAS16 and IAS29) dealing with accounting and changing prices, the PIASA explicitly recommends disclosure of this item in the balance sheet. Additionally, a statement of changes in equity and reconciliation of carrying amounts is recommended. Compliance with the PIASA at this point would require more disclosure from FADN but no change in content. 


\subsection{Revenue recognition}

As far as revenue recognition is concerned, FADN takes an unusual approach, since revenues (called "output") are accounted for based on production. Another concern is the fact that FADN considers subsidies fully earned once these have been granted. Equally notable is the fact that revenues (and expenses) not related to the farm activity are not recorded at all.

Under FADN, revenues derived from livestock and agricultural produce are computed as sales plus (minus) the increase (decrease) in value of inventories. Both sold and unsold production is therefore counted as revenue. This is clearly contradictory with traditional GAAP, that normally only recognize revenues when a sales transaction has taken place, but the PIASA makes a similar proposal. Also IAS18 already referred to production as the moment for income recognition in mining and agriculture under specific conditions (when sales are guaranteed by a government or by a long-term contract, or when a homogeneous market exists that makes the risk of sales failure negligible). In essence, the difference between the PIASA and FADN is that the PIASA values ending inventories of agricultural produce at fair value in their harvested state at the point of harvest (where fair value should be generally identified as market price), while FADN uses year-end prices for both livestock and inventories of agricultural produce.

The experience of the farms we interviewed, the PIASA and the practice of FADN support that revenue recognition based on production is useful for farm accounting. Some authors, like Bublot (1990-1991), also defended this approach. However, valuing ending inventories of agricultural produce at market prices at the point of harvest, introduces in our opinion a complexity that will be difficult to apply in practice. FADN's choice for market prices at closing date seems a much more practical solution. Furthermore, the price at the point of harvest could be confusing for policy makers and other users of accounting information. It 
provides windfall valuations of agricultural production, which may be rather different from the existing prices at the date of ending inventory.

Given that in the European context subsidies often are an important source of income for farms, fully recognizing subsidies as earned in the year that these are granted can lead to important differences compared to the matching-based recognition required by IASC. FADN methodology is probably inspired here by the fact that the EU's accounts are on a spending basis. However, FADN is a complement to macroeconomic data, not a tool to check them; also policy makers would have more reliable data on farm income when subsidies were recorded on accrual basis.

The exclusion of revenues and expenses not related to farm activity shows that the entity concept of FADN is different from common accounting standards. Probably this difference is inspired by the idea that policy makers only have to monitor the direct impact of CAP and need not or should not worry about activities other than farming. It is unclear, however, which policy decisions would benefit from not taking into account the impact of off-farm income on farmers' economies. Moreover, over the years the focus of policy makers has shifted from strictly agricultural income to farm-household income in a broad sense, and since its reform of in 1992 the CAP has been given the more general objective of assuring the viability of rural areas. Since then FADN is aware of the relevance of non-farm activities and income (CEC, 1991). As Leeuwen (1996) points out, many political decisions affect the economic situation of farmers, and information needs in the policy-making process increasingly extend to more aspects than currently captured by FADN. New developments for the FADN methodology are currently under discussion (Robson, 1996). Some authors, like for example Poppe and Beers (1996), accept that the FADN methodology and financial accounting statements are ill-defined 
and should be changed.

In any case, other users of financial statements, like creditors, will normally be interested in information comprehending all business activities. Separate disclosure of income obtained in farming and off-farm activities might be a solution that satisfies the information needs of the different users.

All together, FADN could adapt without major problems to the PIASA with regard to revenue recognition, although a considerable effort would be required to include accounts for activities other than farming.

\subsection{Expenses}

FADN distinguishes four broad categories of expenses. These are called specific costs, overheads, depreciation, and external factors. Depending on the type of farm, the specific cost refer to seeds and plants, fertilizers, crop protection, and other crop specific costs, or feed and other livestock specific costs. Overheads include machinery and building costs, energy, contract work, and other direct inputs. The external factors include wages, rent, and interest. FADN does not consider the remuneration paid to the farmer and his family to be an expense of the farm. The same is true for all social charges whose beneficiaries are family members. Given that the farmer's family in many cases is the major or even only constituent of the workforce, this is of considerable importance. ${ }^{3}$ As mentioned earlier, expenses not related to farm activity are not recorded as farm expenses, either.

Both the specific costs and the overheads are determined on an accrual basis, but the external factors are valued on a cash basis. Depreciation is calculated in accordance with the valuation of the corresponding assets, that is normally on replacement value. Consumption by the farm 
itself of livestock and farm output in general is valued at net realizable value.

The exclusion from FADN of the remuneration of family members can be justified by the fact that the calculation of the "real" cost of family work would require some form of opportunity costing. Amounts paid to family members have more in common with dividends than salaries and do typically not represent their "real" cost. The PIASA does currently not address the issue of family work at all. Although we do not think the opportunity cost of family work can be included in the income statement, perhaps it would be worthwhile to report it in the notes to the financial statements, as this information would certainly be interesting for policy makers. In order to make FADN and the PIASA compatible, we suggest that payments to family members are not accounted for as expenses but as reductions of owners' equity. Regarding social charges paid for the family members, it is unclear why these are not recorded as expenses under FADN. They are based on objective transactions and no opportunity costing is required here.

IASC standards require all of a farm's expenses to be reported, and all of them on an accrual basis. FADN's choice for cash based recognition of the external factors is due to its simplicity and probably also on the presumption that the differences between the cash and accrual basis for these expenses would be relatively small. We believe, however, that it would be preferable to adhere to accrual accounting as the general rule because it is at least conceivable that the differences could be large; in individual cases the materiality principle could still be invoked to justify cash based accounting for some expenses. Furthermore, it can be expected that it will be easier to determine accruals, when information is being collected through an accounting cycle instead of an ex-post questionnaire, as currently is the case with FADN.

As pointed out earlier, there is no apparent conflict with PIASA as far as the use of 
replacement valuations is concerned.

A considerable effort, but no change in "philosophy" would be required to make FADN compatible with the PIASA with regard to this aspect.

\subsection{Financial statement presentation}

Figure 1 shows the structure of the balance sheets prepared by FADN. The asset side only contains a limited number of items, all of which are strictly related to farming activity. In other words, assets not related to the core activities are not shown. On the liability side of the balance sheet, FADN only distinguishes three items. These are owners' equity, long- and medium-term loans, and short-term loans. Although FADN uses the expression "loans", this item includes payables and debts in general. Like the asset side, the liability side only includes items strictly related to farming activity.

Insert Figure 1 approximately here

Furthermore, "change in owners' equity" is included as a separate balance-sheet item. It should not be interpreted as the year's profit or loss, however, because changes may be due to other reasons, like fluctuations in market value of assets, fluctuations in exchange rates, or simply increases or decreases in paid-in capital.

The PIASA does not explicitly refer to other items than those that are specific of agricultural activities, but must, of course, be read in the context of all other IASC standards, which like the 
IVth Directive, obviously require a complete and far more detailed presentation of assets, liabilities and owners' equity on the face of the balance sheet. Compliance with these GAAP would therefore require from FADN substantially more disclosure.

Figure 2 reproduces the structure of the income statements prepared by FADN. Similar to what was pointed out with respect to the balance sheet, the income statement is not really complete, since revenues and expenses not related to farming activities are not shown in it.

Insert Figure 2 approximately here

Although the vocabulary used is sometimes peculiar, it can be seen that the income statement is basically organized by nature of the revenues and expenses. This type of document, if made comprehensive, could be made to fit into one of the formats provided for income statement in the IVth Directive.

The PIASA, on the other hand, is rather brief on income statement presentation. It recommends a classification of revenues and expenses by nature (no conflict with FADN therefore), and a separate identification of the holding gains caused by changes in the fair value of biological assets (which is not provided in FADN yet, but could be obtained easily by splitting out the item “total output").

\section{CONCLUSION}


Farm accounting has not received much attention from accounting researchers, practitioners or standard setters, and in spite of its potential usefulness for farmers and external stakeholders financial statements are generally not very satisfactory or not even prepared at all. The arrival of an IAS on agriculture offers the opportunity to change this situation, but in our opinion its contribution is mainly on a conceptual level and requires additional tools for implementation in practice, like some form of an accounting plan. We argued that FADN could be used to deliver these practical tools, in spite of the fact that it was not initially set up for this purpose. Already now FADN fulfills the role of a guideline and point of reference for agricultural accounting in Europe, and not using it would certainly be a waste of experience and effort. We provided some evidence that farmers who participate in FADN indeed make good use of its reports for other purposes, and acquire consciousness of the importance of accounting and learn to understand and use it. Our data clearly evidence that farms use accounting information as a management tool, for tax requirements and other external information purposes when the problems of obtaining financial statements are solved. It is particularly striking that once accounting information is available to farmers, they very frequently use it for decision making.

It is warranted therefore to analyze the compatibility of FADN and the PIASA. We identified several aspects where the accounting choices made by FADN depart from the accounting principles found in the PIASA. Some of these departures can be considered weak spots of FADN, while others show that not all of the experience of FADN has been taken into account by the IASC yet.

Specifically, we pointed out the following aspects that would have to be modified before FADN procedures could be used to prepare financial statements compatible with the PIASA:

- FADN does not show all assets, liabilities, and owner's equity on the balance sheet; many 
of the items shown are not disclosed in sufficient detail;

- FADN values practically all assets at fair value;

- Not all revenues and expenses are shown on the income statement; many of the items shown are not disclosed in sufficient detail;

- Not all revenues and expenses are determined on an accrual basis;

- Holding gains due to changes in the market price of assets are included in revenues and not disclosed separately.

On the other hand, we have identified some aspects where the PIASA does not seem to take into account the practical experience of FADN or the potential needs of policy makers, who in the case of the EU clearly expressed some of their information needs through the articulation of FADN. Particularly,

- policy makers seem to have a need for separate disclosure of farming and off-farm income, which is not explicitly taken up in the PIASA;

- valuation of ending inventories of agricultural produce at fair value at the point of harvest might be too complicated in practice;

- the particular difficulties relating to the remuneration of family work are not addressed.

A completely different obstacle to the progress of farm accounting in Europe, which has not been fully addressed in this paper, could lay in the regulatory environment. The IVth Directive is silent on most specific issues addressed by FADN; if there is no contradiction between the two, in many cases this is because the Directive is simply not specific enough. We have also 
detected only few contradictions between the PIASA and the IVth Directive, due to the fact that the latter allows for a wide range of accounting practices. However, superficial inspection suggests that there are likely to be many more contradictions between the PIASA and the different implementations of the IVth Directive in the EU member states. It is nevertheless likely that most European farms will eventually be able to use the PIASA, not in the last place because given their small size or legal form they have no obligation to publish financial statements according to any specific accounting rules.

A remaining question is who should extract the "cooking book" out of FADN. According to a well-known saying, giving a man a fish will feed him for one day, while giving him a cane will allow him to feed himself every day. By analogy, giving a farmer a subsidy will keep him from going bankrupt for one year, but giving him management tools, e.g. accounting tools, will allow him to become self-sustainable. Many institutions should be very interested in this prospect, including the European Commission, national governments, farmer associations, and the FADN itself. 


\section{References}

Alonso, R. and Serrano, A. (1991) Los Costes en los Procesos de Producción Agraria. Madrid: Mundi-Prensa.

Allen, R. (1994) "Farm potential: high tech leads the average farmer's know-how", Texas Banking, 88 (11): 26.

American Institute of Certified Public Accountants (1996) Audits of Agricultural Producers and Agricultural Cooperatives. New York: AICPA.

André, F. (1987) "Vers un renouveau de la formation économique des agriculteurs?", Économie Rurale, 177: 53-56.

Argilés, J.M. (1998) "Accounting information and the prediction of farm viability", Economics Working Paper 277, Barcelona: Universitat Pompeu Fabra.

Bronstien, B.F. (1995) American Banker, "Group seeking to bring more farmers into line on financial reporting", 27 November 1995: 8.

Bublot, G. (1990-1991) Economie et Gestion de l'Exploitation Agricole Volumes I et II. Lovain: Université Catholique de Louvain, Faculté des Sciences Agronomiques.

Canadian Institute of Chartered Accountants (1986) Comptabilité et Information Financière des Producteurs Agricoles. Toronto: CICA.

Cairns, D. (1997) “The future shape of harmonization: a reply”, European Accounting Review, 6(2): $305-348$

CEC (1990) Red de Información Contable Agrícola. Vademécum de Metodología. Luxembourg: Office for Official Publications of the European Communities.

CEC (1991) The Calculation of Economic Indicators Making Use of RICA (FADN) Accountancy Data. Luxembourg: Office for Official Publications of the European Communities.

CEC (1997) "Data definitions and instructions for the FADN farm return", Community Committee for the Farm Accountancy Data Network, RI/CC 1256 prov.

CEC (1998) "Definitions of variables used in FADN standard results", Community Committee for the Farm Accountancy Data Network, RI/CC 882 Rev.6.

Chaveau, B. (1995) "The Spanish Plan General de Contabilidad; Agent of development and innovation?," European Accounting Review, 4(1): 125-138. 
Choi, F.D.S and Mueller, G.G. (1992) International Accounting, Englewood Cliffs (NJ): Prentice-Hall (2nd ed.).

Crane, L.M. and Leatham, D.J. (1995) "External equity financing in agriculture via profit and loss sharing contracts: a proposed financial innovation”, Agribusiness, 11 (3): 223-233.

Dedman, S. (1996) "FADN/RICA and the requirements of financial institutions", in Beers, G., Poppe, K.J. and Pruis, H.C. (eds) Pacioli 2 Accounting and Managing Innovation. The Hague: Agricultural Research Institute LEI-DLO 534, pp.151-157.

Domínguez, D. (1981) Cuestiones Especiales Relativas a La Administración y Contabilidad de las Empresas Agrícola-Ganaderas. Madrid: Técnica Bellisco.

Flower, J. (1997) “The future shape of harmonization: the EU versus the IASC versus the SEC", European Accounting Review, 6(2): 281-303.

Flower, J. (1998) “The future shape of harmonization: a reply”, European Accounting Review, 7(2): 331-333.

Garcia, P. Sonka, S.T. and Mazzacco, M.A. (1983), "A Multivariate Logit Analysis of Farmers' Use of Financial Information", American Journal of Agricultural Economics, 65(1) 136-141.

International Accounting Standards Committee (1999), Proposed International Accounting Standard Agriculture. London: IASC.

Kroll, J.C. (1987) “Le nouveau plan comptable: les occasions perdues”, Économie Rurale, 180: $20-25$.

Launay, R., Beaufrere, J.P. and Debroise, G. (1967) L'entreprise Agricole Analyse, Diagnostic, Prévision. Paris: Librairie Armand Colin.

Leeuwen, G. (1996) "Policy-making and Farm Accountancy Data Network", in Beers, G., Poppe, K.J. and Pruis, H.C. (eds) Pacioli 2 Accounting and Managing Innovation.

Lewis, A.E. and Jones, W.D. (1980) "Current cost accounting and farming businesses", Journal of Agricultural Economics, 31: 45-53.

Luening, R.A. (1989) "Farm records can improve profitability", in United States Department of Agriculture, (eds.) Farm Management: How to Achieve your Farm Business Goals. US. Washington: Government Printing Office, pp. 103-112.

Pérez, J.A. (1993) "La problemática contable del inmovilizado en las empresas ganaderas", Técnica Contable, 538: 625-636. 
Poppe, K.J. (1991) "Information needs and accounting in agriculture", Agricultural Economics Research Institute LEI, 444: 1-51.

Poppe, K.J. and Beers, G. (1996) "On innovation management in Farm Accountancy Data Networks", Agricultural Economics Research Institute LEI, 535: 1-37.

Poppe, K.J. and Breembroek, J.A. (1992) “The assessment of a farm's financial situation with a report writer", Tijdschrift voor Sociaalwetenschappelijk onderzoek, 7(1): 49-70.

Richard, J. (1995) "The evolution of accounting chart models in Europe from 1900 to 1945; Some historical elements", European Accounting Review, 4(1): 87-124.

Robson, N. (1996) 'The Farm Accountancy Data Network and policy making”, in Beers, G., Poppe, K.J. and Pruis, H.C. (eds.) Pacioli 2 Accounting and Managing Innovation.

Sabaté, P. and Enciso, J.P. (1997) "La valoración de inmovilizados en las empresas agrarias. El caso de las plantaciones", Técnica Contable, 579: 177-184.

Streeter, D.H. (1990) "Electronic information systems and farmers decision making: Five case studies”, European Review of Agricultural Economics, 19: 97-113.

Sturgess, I. (1994) 'Ce qu'apporte la théorie économique a la mesure et l'interpretation des revenus agricoles", Économie Rurale, 220-221: 11-15. 
Figure 1; Structure of FADN balance sheets

\begin{tabular}{|l|l|}
\hline Fixed assets: & Net worth \\
Land and permanent crops & Change in net worth \\
Buildings & \\
Machinery & Long- and medium-term loans \\
Breeding livestock & \\
Current assets: & Short-term loans \\
Non-breeding livestock & \\
Stock agricultural products & \\
Other circ. capital & \\
\hline
\end{tabular}


Figure 2; Structure of FADN Income Statements

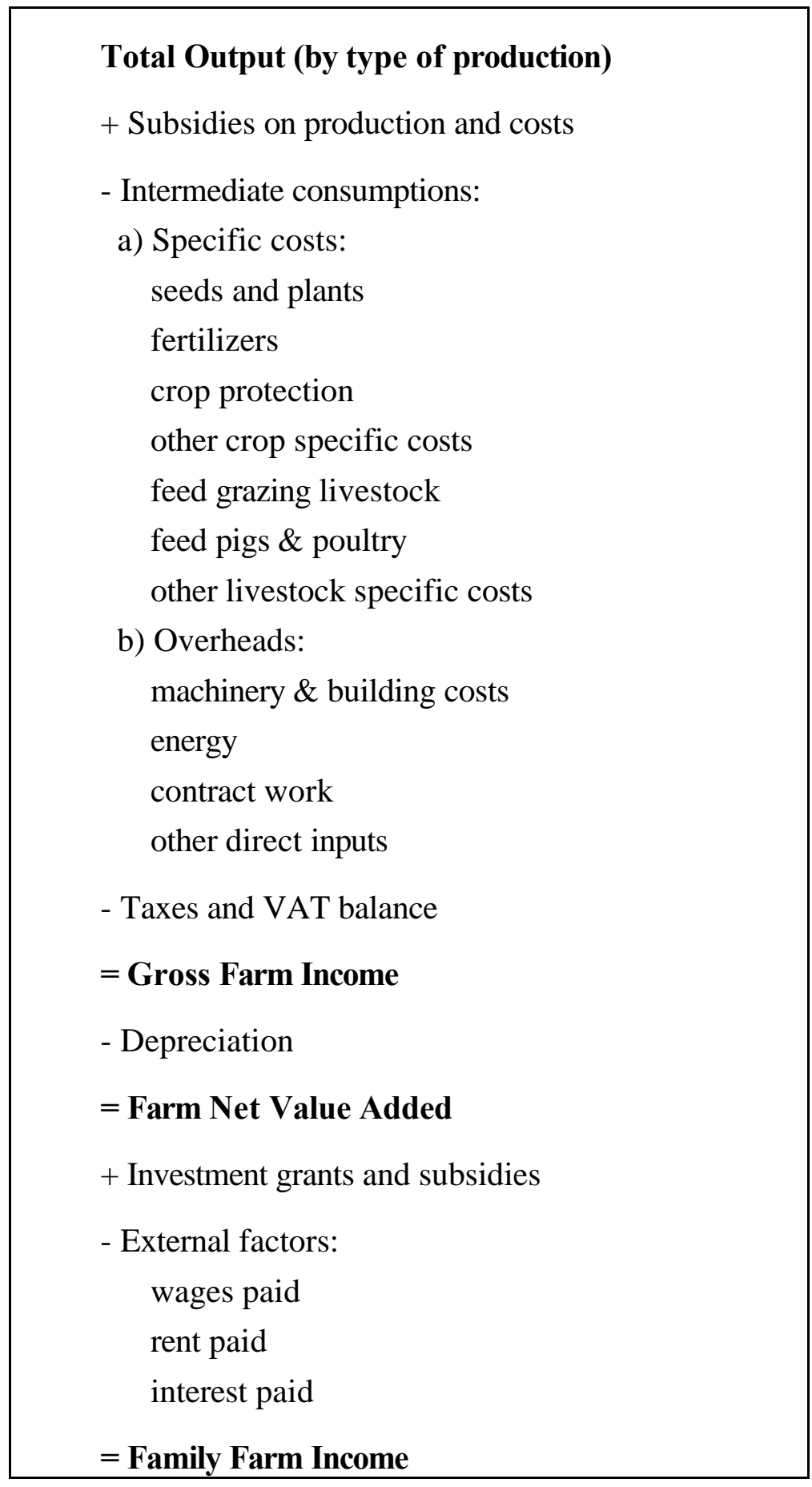




\begin{tabular}{|c|c|c|}
\hline & \multicolumn{2}{|c|}{$\begin{array}{c}\text { Total number of times } \\
\text { mentioned }\end{array}$} \\
\hline & (number) & $(\%)$ \\
\hline $\begin{array}{l}\text { Only prepared information } \\
\text { for FADN }\end{array}$ & 311 & 45,4 \\
\hline $\begin{array}{l}\text { Also used information for } \\
\text { other purposes }\end{array}$ & $\underline{374}$ & $\underline{54,6}$ \\
\hline Total & 685 & 100,0 \\
\hline
\end{tabular}

Table 2. Different uses of FADN reports

\begin{tabular}{|c|c|c|c|c|c|c|}
\hline & \multicolumn{2}{|c|}{$\begin{array}{l}\text { Mentioned at least in one } \\
\text { of the five years }\end{array}$} & \multicolumn{2}{|c|}{$\begin{array}{l}\text { Mentioned in each of the } \\
\text { five years }\end{array}$} & \multicolumn{2}{|c|}{$\begin{array}{c}\text { Total number of times } \\
\text { mentioned }\end{array}$} \\
\hline & $\begin{array}{r}\text { (number of } \\
\text { farms) } \\
\end{array}$ & $\begin{array}{r}(\%) \\
\mathrm{N}=137^{\mathrm{a}} \\
\end{array}$ & $\begin{array}{r}\text { (number of } \\
\text { farms) } \\
\end{array}$ & $\begin{array}{r}(\%) \\
\mathrm{N}=137^{\mathrm{a}} \\
\end{array}$ & (number) & $\begin{array}{r}(\%) \\
\mathrm{N}=685^{\mathrm{b}} \\
\end{array}$ \\
\hline $\begin{array}{l}\text { Only prepared } \\
\text { information } \\
\text { for FADN }\end{array}$ & 66 & 48,2 & 58 & 42,3 & 311 & 45,4 \\
\hline $\begin{array}{l}\text { Also used information } \\
\text { for other purposes }{ }^{c} \text { : }\end{array}$ & & & & & & \\
\hline - loan application & 6 & 4,4 & 4 & 2,9 & 16 & 2,3 \\
\hline - subsidy application & 9 & 6,6 & 4 & 2,9 & 26 & 3,8 \\
\hline - income tax filing & 58 & 42,3 & 53 & 38,7 & 275 & 40,1 \\
\hline - management decisions & 57 & 41,6 & 52 & 38,0 & 273 & 39,9 \\
\hline
\end{tabular}


APPENDIX; Excerpts from "Data definitions and Instructions for the FADN FARM RETURN"

(CEC, 1997)

FEEDINGSTUFFS :

Feedingstuffs are divided into those purchased and those produced and used on the farm.

Purchased feedingstuffs include mineral licks, milk products (bought or returned to the farm) and products for the preservation and storage of feedingstuffs. Also included are expenditure on agistment, on the use of common pasture and grazing land and on renting of other forage areas not included in the UAA.

Purchased litter and straw are also included with purchased feedingstuffs.

Feedingstuffs purchased for grazing stock are subdivided into concentrated feedingstuffs. (the heading 'Concentrated feedingstuffs' includes in particular oilcakes, compound feeds, cereals, dried grass, dried sugar beet pulp, fish and meat meal, milk and dairy products, minerals and products for the preservation and storage of feedingstuffs), and coarse fodder (including agistment and expenditure on the use of common pastures, grazing land and forage land not included in the UAA, and purchased litter and straw. Feedingstuffs produced are used on the farm include saleable farm products used as feedingstuffs(including milk products but excluding milk suckled by calves, which is not taken into account). Litter and straw produced on the holding are only included if they are a saleable product in the region and year in question. Expenditure on work carried out by agricultural contractors for the production of coarse fodder, e.g. silage, is entered under heading 60 'Contract work'.

Feedingstuffs produced and used on the farm include saleable farm products used as feedingstuffs (including milk and milk products but excluding milk suckled by calves, which is not taken into account). Litter and straw produced on the holding are only included if they are a saleable product in the region and year in question.

Purchased feedingstuffs for grazing stock (equines, cattle, sheep, goats).

64. Concentrated feedingstuffs

65. Coarse fodder

Purchased feedingstuffs for :

66.Pigs

67. Poultry and other small animals

Farm-produced feedingstuffs for :

68. Grazing stock (equines, cattle, sheep, goats)

69.Pigs

70.Poultry and other small animals 


\section{Categories of grants and subsidies}

All amounts in the accounting data are exclusive of grants and subsidies. Grants and subsidies are understood to be direct aids granted from public funds and which give rise to a payment or specific right (cf. headings 112 to 119 ).

- $\quad$ grants and subsidies on products due during the accounting year are entered under headings 112 and 113 .

grants and subsidies on animals due during the accounting year are entered under headings 112 and 113 .

grants and subsidies on costs (except purchases of animals - see below) or due during the accounting year are entered under headings 114 and 115 .

grants and subsidies on purchases of animals due during the accounting year are entered under headings 116 and 117 .

grants and subsidies on investments received during the accounting year are entered in column 5 of table $G$.

subsidies on interest paid received during the accounting year are entered under headings 114 and 115.

extraordinary grants and subsidies received during the accounting year are entered under headings 112 and 113 .

differences in grants and subsidies (other than on investments) relative to amounts returned as due in previous accounting years are entered under serial number 483. 


\section{Depreciation (column 7)}

The depreciation to be shown is the actual amount of depreciation over the accounting year as shown in the accounts. It is determined on the basis of the replacement value (i.e. value at current prices of a similar asset).

\section{DEPRECIATION}

Depreciation is to be calculated at replacement value before deduction of subsidies.

The amount indicated in column 7 should normally be nil for headings 95 (Agricultural land) and 102

(Circulating capital)

\section{Depreciation of plantations}

The cost of young trees and bushes for a new plantation represents a capital asset subject to depreciation. Only plantations which are the property of the holder, irrespective of the type of occupancy of the land, are subject to depreciation.

Depreciation of farm buildings, fixed equipment and land improvements

Depreciation of buildings, fixed equipment (including glasshouses and frames) and land improvements belonging to the holder, irrespective of the type of occupancy of the land.

Depreciation of machinery and equipment

Machinery and equipment subject to depreciation is defined as that having a value when new greater than 100 ECU. The depreciation of minor equipment of lower value should not be calculated; purchases of such equipment are to be treated directly as costs for the accounting year (heading 61 'Current upkeep of machinery and equipment').

Major repairs which effectively increase the value of the machinery are also included under this heading. They should either be integrated into machinery or equipment depreciation, which will be adjusted to take account of the longer life (due to the repairs) of the item(s) in question or entered as increased major machinery costs (the cost of repairs) spread over several successive years.

The amount of annual depreciation may be calculated according to the linear or diminishing balance method. The rate of depreciation is determined by various factors, which depend for the most part on the particular conditions of the region and of the production in question (amount of use in each year) but also on technical progress.

In view of regional differences in depreciation method, and even from one holding to another, accountancy offices may choose rates for each item of machinery or equipment appropriate to the region or holding. The aim is to keep as close as possible to the actual deprecation in value of the machinery. 


\section{Endnotes:}

${ }^{1}$ FADN is also known as RICA, its acronym in French.

${ }^{2}$ Historical cost is not only difficult to apply on farms; we had the opportunity to interview a poultry processing company. This company values its products, according to their weight, at the purchase price of the chicken, because it is unable to find a satisfactory solution to the allocation of joint processing costs.

3. Contradictorily, family farm work is included in the valuation of of self- constructed fixed assets. 